\title{
Hydrogen Permeable Nb-Based Amorphous Alloys with High Thermal Stability
}

\author{
H. Y. Ding ${ }^{1,2}$, W. Zhang ${ }^{2,3}$, S. I. Yamaura ${ }^{2}$ and K. F. Yao ${ }^{1, *}$ \\ ${ }^{1}$ School of Materials Science and Engineering, Tsinghua University, Beijing 100084, P.R. China \\ ${ }^{2}$ Institute for Materials Research, Tohoku University, Sendai 980-8577, Japan \\ ${ }^{3}$ School of Materials Science and Engineering, Dalian University of Technology, Dalian 116024, P.R. China
}

\begin{abstract}
In this work, the $\mathrm{Nb}$-based $\mathrm{Nb}_{42} \mathrm{Ni}_{40} \mathrm{Co}_{18-x} \mathrm{Zr}_{x}(x=0,4,12)$ and $\mathrm{Nb}_{42} \mathrm{Ni}_{32} \mathrm{Co}_{6} \mathrm{Zr}_{12} \mathrm{M}_{8}(\mathrm{M}=\mathrm{Ta}$, Ti, Zr) amorphous alloy ribbons were successfully prepared by single roller melt-spinning technique. These amorphous alloys exhibit high thermal stability with the crystallization temperature $\left(T_{\mathrm{x}}\right)$ exceeding $850 \mathrm{~K}$. It has been found that $T_{\mathrm{x}}$ of the $\mathrm{Nb}_{42} \mathrm{Ni}_{40} \mathrm{Co}_{18}$ alloy decreased with $\mathrm{Zr}$ addition, while hydrogen permeability increased linearly with $\mathrm{Zr}$ content. The hydrogen permeability of the $\mathrm{Nb}_{42} \mathrm{Ni}_{40} \mathrm{Co}_{18}, \mathrm{Nb}_{42} \mathrm{Ni}_{40} \mathrm{Co}_{14} \mathrm{Zr}_{4}, \mathrm{Nb}_{42} \mathrm{Ni}_{40} \mathrm{Co}_{6} \mathrm{Zr}_{12}$ and $\mathrm{Nb}_{42} \mathrm{Ni}_{32} \mathrm{Co}_{6} \mathrm{Zr}_{20}$ amorphous alloys at $673 \mathrm{~K}$ are $0.03 \times 10^{-8}, 0.23 \times 10^{-8}, 0.69 \times 10^{-8}$ and $1.40 \times 10^{-8} \mathrm{~mol}^{-1} \cdot \mathrm{m}^{-1} \cdot \mathrm{s}^{-1} \cdot \mathrm{Pa}^{-1 / 2}$, respectively. It is noticed that hydrogen permeability of the $\mathrm{Nb}_{42} \mathrm{Ni}_{32} \mathrm{Co}_{6} \mathrm{Zr}_{20}$ alloy is comparable with that of $\mathrm{Pd}-23 \% \mathrm{Ag}$ alloy $\left(1.14 \times 10^{-8}\right)$. Meanwhile, permeability of the above mentioned alloy decreased to $60 \%$ of the initial value while it still maintains amorphous structure after $24 \mathrm{~h}$ long term durability test. Both thermal stability and hydrogen permeability are enhanced by substituting 8 at $\%$ Ni with Ta or Ti in the $\mathrm{Nb}_{42} \mathrm{Ni}_{40} \mathrm{Co}_{6} \mathrm{Zr}_{12}$ alloy. The present result indicates that the $\mathrm{Nb}$-based amorphous alloys possess the potential of applying as a kind of hydrogen permeable membrane at high temperature. [doi:10.2320/matertrans.MF201310]
\end{abstract}

(Received January 28, 2013; Accepted April 5, 2013; Published July 25, 2013)

Keywords: amorphous alloy, niobium-based alloy, thermal stability, hydrogen permeation

\section{Introduction}

In order to solve the problems such as energy crisis and environmental pollution caused by excessive consumption of fossil fuels nowadays, people are trying to find other kinds of energy. Among them, hydrogen energy attracts much attention because of its high efficiency and no pollution. For the large scale application of hydrogen energy, a whole system including the production, purification, storage, distribution and utilizing of hydrogen needs to be established. The purification of hydrogen is an important procedure because in many cases such as semiconductor industry and fuel cells, pure hydrogen is necessary. However, the hydrogen produced by steam reforming contains lots of other contamination gases, e.g., $\mathrm{O}_{2}, \mathrm{~N}_{2}, \mathrm{CO}, \mathrm{CO}_{2}, \mathrm{CH}_{4}$ and so on, ${ }^{1)}$ which is detrimental for the application of hydrogen. Traditionally, Pd and Pd-alloys have been used as hydrogen permeable membranes to obtain pure hydrogen, especially the $\mathrm{Pd}-\mathrm{Ag}^{2)}$ and $\mathrm{Pd}-\mathrm{Cu}^{3)}$ alloys are now commercially available. Since $\mathrm{Pd}$ is a noble metal with high price and limited resources, the development of substitute materials with lower cost for hydrogen purification is becoming a very urgent task.

Amorphous alloy is a kind of material without crystalline structure and has very high strength ${ }^{4-7)}$ due to the absence of dislocations. By single roller melt-spinning, thin amorphous alloy membrane can be obtained easily, while the conventional Pd-based alloys need repeated rolling and subsequent annealing to be a thinner membrane. ${ }^{8)}$ During the past few years, there are many papers on hydrogen permeable amorphous alloy membranes. ${ }^{9-21)}$ Table 1 lists the main results on this subject. Hara et al. investigated the hydrogen permeability of $\mathrm{Ni}-\mathrm{Zr}$ amorphous alloys ${ }^{9)}$ and the effect of $\mathrm{Ti}$ or $\mathrm{Hf}$ addition. ${ }^{10)}$ Yamaura et al. designed the $\mathrm{Ni}-\mathrm{Nb}-\mathrm{Zr}$ alloy system and found that the hydrogen permeability increased with increasing $\mathrm{Zr}$ content ${ }^{11)}$ and that further

*Corresponding author, E-mail: kfyao@tsinghua.edu.cn
Table 1 Crystallization temperature $\left(T_{\mathrm{x}}\right)$ and hydrogen permeability of the amorphous alloy membranes as compared with $\mathrm{Pd}_{77} \mathrm{Ag}_{23}$ alloy.

\begin{tabular}{cccc}
\hline Composition & $T_{\mathrm{x}}(\mathrm{K})$ & $\begin{array}{c}\text { Permeability }(673 \mathrm{~K}), \\
\times 10^{-8} \mathrm{~mol} \cdot \mathrm{m}^{-1} \cdot \mathrm{s}^{-1} \cdot \mathrm{Pa}^{-1 / 2}\end{array}$ & Year \\
\hline $\mathrm{Ni}-\mathrm{Zr}{ }^{9)}$ & 833 & $0.12($ at $623 \mathrm{~K})$ & 2000 \\
$\mathrm{Ni}-(\mathrm{Ti}, \mathrm{Hf})-\mathrm{Zr}^{10)}$ & $\sim 820$ & $<0.12$ & 2002 \\
$\mathrm{Ni}-\mathrm{Nb}-\mathrm{Zr}^{11)}$ & $800-910$ & $0.11-1.30$ & 2003 \\
$\mathrm{Ni}-\mathrm{Nb}-\mathrm{Zr}-(\mathrm{Co}, \mathrm{Cu})^{12)}$ & $720-740$ & $2.34-2.46$ & 2004 \\
$\mathrm{Zr}-\mathrm{Al}-\mathrm{Co}-\mathrm{Ni}-\mathrm{Cu}^{13)}$ & $<800$ & 1.13 & 2004 \\
$\mathrm{Ni}-\mathrm{Nb}-\mathrm{Zr}^{14)}$ & $<800$ & 1.59 & 2005 \\
$\mathrm{Ni}-\mathrm{Ti}-\mathrm{Zr}{ }^{15)}$ & $<750$ & 1.05 & 2005 \\
$\mathrm{Ni}-\mathrm{Nb}-\mathrm{Ti}-\mathrm{Zr}^{17)}$ & 903 & $2.50-2.89($ at $773 \mathrm{~K})$ & 2008 \\
$\mathrm{Ni}-\mathrm{Ta}-\mathrm{Zr}{ }^{18)}$ & 865 & 0.86 & 2009 \\
$\mathrm{Ni}-\mathrm{Nb}-\mathrm{Ta}-\mathrm{Zr}-\mathrm{Co}{ }^{19)}$ & 820 & 0.97 & 2010 \\
$\mathrm{Ni}-\mathrm{Nb}-(\mathrm{Ta})-\mathrm{Zr}^{20)}$ & $800-900$ & $1.40($ at $723 \mathrm{~K})$ & 2011 \\
$\mathrm{Pd}{ }_{77} \mathrm{Ag}{ }_{23}{ }^{9)}$ & - & $1.5($ at $623 \mathrm{~K})$ & 2000 \\
\hline
\end{tabular}

alloying with $\mathrm{Co}$ or $\mathrm{Cu}$ is beneficial for the permeability. ${ }^{12-14)}$ Further investigations in the $\mathrm{Ni}-\mathrm{X}-\mathrm{Zr}$ alloys revealed that $\mathrm{Ni}$ content should be reduced to improve hydrogen permeability. ${ }^{15)}$ Lee et al. developed the $\mathrm{Ni}-\mathrm{Nb}-\mathrm{Ti}-\mathrm{Zr}$ amorphous alloys with improved permeability at higher temperature. ${ }^{17)}$ Qiang et al. discussed the effect of $\mathrm{Ta}$ substitution for $\mathrm{Nb}$ in the $\mathrm{Ni}-\mathrm{Nb}-\mathrm{Zr}$ alloy and found that $\mathrm{Ta}$ is effective in improving its thermal stability without severely deteriorating the permeability. ${ }^{18)}$ It can be seen from Table 1 that some membranes possess permeability comparable with or even better than that of Pd-alloys. So, amorphous alloy may be a potential candidate as a hydrogen permeable membrane in the future, while much research work is still required.

Since amorphous alloy is a kind of metastable material, when the temperature exceeds its crystallization temperature $\left(T_{\mathrm{x}}\right)$ it tends to crystallize and the properties associated with the amorphous structure will disappear. Therefore, enhancing the thermal stability of amorphous alloy is very important for 
Table 2 Composition, thermal property and hydrogen permeability of the $\mathrm{Nb}_{42} \mathrm{Ni}_{40} \mathrm{Co}_{18-x} \mathrm{Zr}_{x}(x=0,4,12)$ and $\mathrm{Nb}_{42} \mathrm{Ni}_{32} \mathrm{Co}_{6} \mathrm{Zr}_{12} \mathrm{M}_{8}(\mathrm{M}=\mathrm{Ta}, \mathrm{Ti}$, $\mathrm{Zr}$ ) amorphous alloy membranes as well as $\mathrm{Pd}-23 \% \mathrm{Ag}$ alloy.

\begin{tabular}{cccccc}
\hline \multirow{2}{*}{ Composition } & $T_{\mathrm{x}}(\mathrm{K})$ & \multicolumn{4}{c}{ Permeability, $\times 10^{-8} \mathrm{~mol} \cdot \mathrm{m}^{-1} \cdot \mathrm{s}^{-1} \cdot \mathrm{Pa}^{-1 / 2}$} \\
\cline { 3 - 6 } & & $723 \mathrm{~K}$ & $673 \mathrm{~K}$ & $623 \mathrm{~K}$ & $573 \mathrm{~K}$ \\
\hline $\mathrm{Nb}_{42} \mathrm{Ni}_{40} \mathrm{Co}_{18}$ & 913 & 0.05 & 0.03 & - & - \\
$\mathrm{Nb}_{42} \mathrm{Ni}_{40} \mathrm{Co}_{14} \mathrm{Zr}_{4}$ & 894 & 0.28 & 0.23 & 0.17 & - \\
$\mathrm{Nb}_{42} \mathrm{Ni}_{40} \mathrm{Co}_{6} \mathrm{Zr}_{12}$ & 868 & - & 0.69 & 0.52 & 0.42 \\
$\mathrm{Nb}_{42} \mathrm{Ni}_{32} \mathrm{Co}_{6} \mathrm{Zr}_{12} \mathrm{Ta}_{8}$ & 936 & - & 0.88 & 0.67 & 0.47 \\
$\mathrm{Nb}_{42} \mathrm{Ni}_{32} \mathrm{Co}_{6} \mathrm{Zr}_{12} \mathrm{Ti}_{8}$ & 946 & - & 1.30 & 1.01 & 0.75 \\
$\mathrm{Nb}_{42} \mathrm{Ni}_{32} \mathrm{Co}_{6} \mathrm{Zr}_{20}$ & 859 & - & 1.40 & 0.95 & 0.60 \\
$\mathrm{Pd}_{2} 23 \% \mathrm{Ag}$ & - & - & 1.14 & 0.85 & 0.58 \\
\hline
\end{tabular}

its practical application. ${ }^{18-22)}$ We can see that most alloys listed in Table 1 are Ni-based alloys and their $T_{\mathrm{x}}$ are relatively low, resulting that their thermal stability is a little insufficient. So, developing hydrogen permeable amorphous alloys with higher $T_{\mathrm{x}}$ is meaningful. In this work, we designed the $\mathrm{Nb}_{42} \mathrm{Ni}_{40} \mathrm{Co}_{18-x} \mathrm{Zr}_{x}(x=0,4,12)$ and $\mathrm{Nb}_{42} \mathrm{Ni}_{32}-$ $\mathrm{Co}_{6} \mathrm{Zr}_{12} \mathrm{M}_{8}(\mathrm{M}=\mathrm{Ta}$, Ti, $\mathrm{Zr})$ alloys based on the following considerations: Niobium $(\mathrm{Nb})$ based amorphous alloy is seldom reported; meanwhile $\mathrm{Nb}$ is an element with high melting temperature and possesses good hydrogen permeation property in crystalline state. So, we investigated the properties of $\mathrm{Nb}$-based $\mathrm{Nb}_{42} \mathrm{Ni}_{40} \mathrm{Co}_{18-x} \mathrm{Zr}_{x}(x=0,4,12)$ and $\mathrm{Nb}_{42} \mathrm{Ni}_{32} \mathrm{Co}_{6} \mathrm{Zr}_{12} \mathrm{M}_{8}(\mathrm{M}=\mathrm{Ta}, \mathrm{Ti}, \mathrm{Zr})$ alloys to see whether it can be made amorphous or not and whether it is suitable for hydrogen permeation or not. We designed the ternary $\mathrm{Nb}_{42} \mathrm{Ni}_{40} \mathrm{Co}_{18}$ alloy as a base alloy by replacing $\mathrm{Ta}$ with $\mathrm{Nb}$ in the $\mathrm{Ta}_{42} \mathrm{Ni}_{40} \mathrm{Co}_{18}$ alloy, which was reported to form a bulk metallic glass with a critical diameter of $2 \mathrm{~mm} .{ }^{23)}$ By substituting $\mathrm{Co}$ with $\mathrm{Zr}$, quaternary $\mathrm{Nb}_{42} \mathrm{Ni}_{40} \mathrm{Co}_{18-x} \mathrm{Zr}_{x}$ $(x=0,4,12)$ alloys are obtained. Further substitution of $\mathrm{Ni}$ with $\mathrm{Ta}$, Ti and $\mathrm{Zr}$ leads to the $\mathrm{Nb}_{42} \mathrm{Ni}_{32} \mathrm{Co}_{6} \mathrm{Zr}_{12} \mathrm{M}_{8}$ $(\mathrm{M}=\mathrm{Ta}, \mathrm{Ti}, \mathrm{Zr})$ alloys. They were listed in Table 2 .

\section{Experimental}

Nb-based $\mathrm{Nb}_{42} \mathrm{Ni}_{40} \mathrm{Co}_{18-x} \mathrm{Zr}_{x}(x=0,4,12)$ and $\mathrm{Nb}_{42} \mathrm{Ni}_{32}-$ $\mathrm{Co}_{6} \mathrm{Zr}_{12} \mathrm{M}_{8}(\mathrm{M}=\mathrm{Ta}, \mathrm{Ti}, \mathrm{Zr})$ alloys were prepared by arcmelting the mixture of pure metals (purity higher than 99.9\%) under a Ti-getter argon atmosphere, the master alloys were remelted four times for composition homogeneity. By single roller melt-spinning method, we obtained the ribbon samples approximately $10 \mathrm{~mm}$ in width and $50 \mu \mathrm{m}$ in thickness. The samples were polished and sputtered with Pd coating on both sides, the thickness of the coating is about $100 \mathrm{~nm}$. Hydrogen permeability was tested by the conventional gas permeation technique at 573, 623, 673 and $723 \mathrm{~K}$, respectively. The permeation area is about $5 \mathrm{~mm}$ in diameter, the lower side pressure was kept to be $0.1 \mathrm{MPa}$ and the upper pressure was up to $0.3 \mathrm{MPa}$ (for the $\mathrm{Nb}_{42} \mathrm{Ni}_{32} \mathrm{Co}_{6} \mathrm{Zr}_{12} \mathrm{M}_{8}(\mathrm{M}=\mathrm{Ta}, \mathrm{Ti}, \mathrm{Zr}$ ) alloys the maximum pressure was $0.2 \mathrm{MPa}$ ).

Microstructure of the ribbon samples was studied by a Rigaku D/max-RB X-ray diffraction spectrometry (XRD) with $\mathrm{Cu} \mathrm{K} \alpha$ radiation. Thermal properties of the samples were examined by differential scanning calorimeter (DSC) instrument in an Ar gas flow at a heating rate of $20 \mathrm{~K} / \mathrm{min}$.

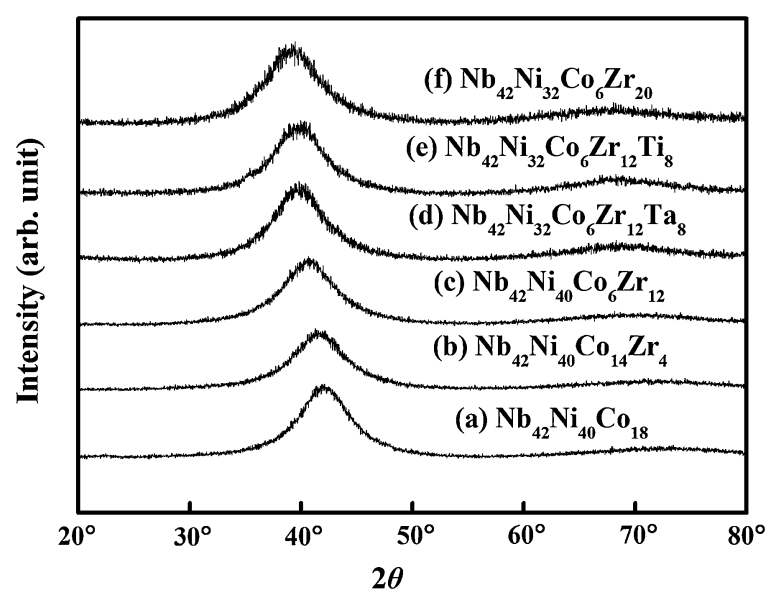

Fig. $1 \mathrm{XRD}$ spectra of the $\mathrm{Nb}_{42} \mathrm{Ni}_{40} \mathrm{Co}_{18-x} \mathrm{Zr}_{x} \quad(x=0,4,12)$ and $\mathrm{Nb}_{42} \mathrm{Ni}_{32} \mathrm{Co}_{6} \mathrm{Zr}_{12} \mathrm{M}_{8}(\mathrm{M}=\mathrm{Ta}, \mathrm{Ti}, \mathrm{Zr})$ alloy ribbons.

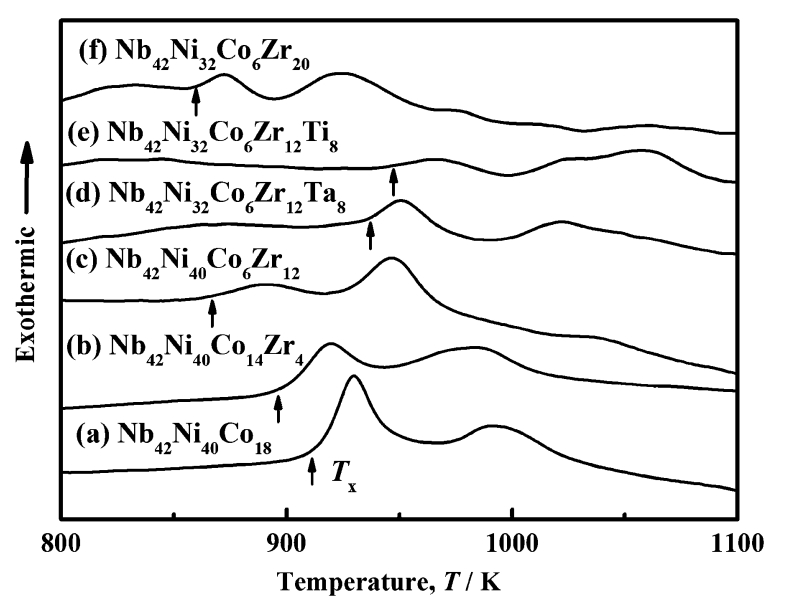

Fig. 2 DSC curves of the $\mathrm{Nb}_{42} \mathrm{Ni}_{40} \mathrm{Co}_{18-x} \mathrm{Zr}_{x} \quad(x=0,4,12)$ and $\mathrm{Nb}_{42} \mathrm{Ni}_{32} \mathrm{Co}_{6} \mathrm{Zr}_{12} \mathrm{M}_{8}(\mathrm{M}=\mathrm{Ta}, \mathrm{Ti}, \mathrm{Zr})$ alloy ribbons.

The depth profile and compositional variations of the Pdcoated $\mathrm{Nb}$-based amorphous alloy after hydrogen permeation was measured by ULVAC-PHI, Inc. type Auger electron spectroscopy (AES).

\section{Results and Discussion}

Figure 1 shows the XRD patterns of the melt-spun $\mathrm{Nb}$ based $\mathrm{Nb}_{42} \mathrm{Ni}_{40} \mathrm{Co}_{18-x} \mathrm{Zr}_{x}(x=0,4,12)$ and $\mathrm{Nb}_{42} \mathrm{Ni}_{32}-$ $\mathrm{Co}_{6} \mathrm{Zr}_{12} \mathrm{M}_{8}(\mathrm{M}=\mathrm{Ta}, \mathrm{Ti}, \mathrm{Zr})$ alloy ribbons. The XRD spectra are characterized by a broad diffraction halo without any sharp crystalline peaks within the whole scanning range. All the melt-spun samples were identified to possess amorphous structure.

The DSC curves of the melt-spun $\mathrm{Nb}_{42} \mathrm{Ni}_{40} \mathrm{Co}_{18-x} \mathrm{Zr}_{x}$ $(x=0,4,12)$ and $\mathrm{Nb}_{42} \mathrm{Ni}_{32} \mathrm{Co}_{6} \mathrm{Zr}_{12} \mathrm{M}_{8}(\mathrm{M}=\mathrm{Ta}, \mathrm{Ti}, \mathrm{Zr})$ alloy ribbons are shown in Fig. 2. The crystallization temperatures $\left(T_{\mathrm{x}}\right)$ are marked with arrows in Fig. 2 and listed in Table 2. There is no detectable glass transition before crystallization for all the alloys studied. These curves basically comprise of two main crystallization peaks. In the $\mathrm{Nb}-\mathrm{Ni}-\mathrm{Co}-\mathrm{Zr}$ quaternary alloys, crystallization temperature $T_{\mathrm{x}}$ decreased with increasing $\mathrm{Zr}$ content. $T_{\mathrm{x}}$ of the $\mathrm{Nb}_{42} \mathrm{Ni}_{32} \mathrm{Co}_{6} \mathrm{Zr}_{20}$ alloy $(859 \mathrm{~K})$ is $54 \mathrm{~K}$ lower than that of 

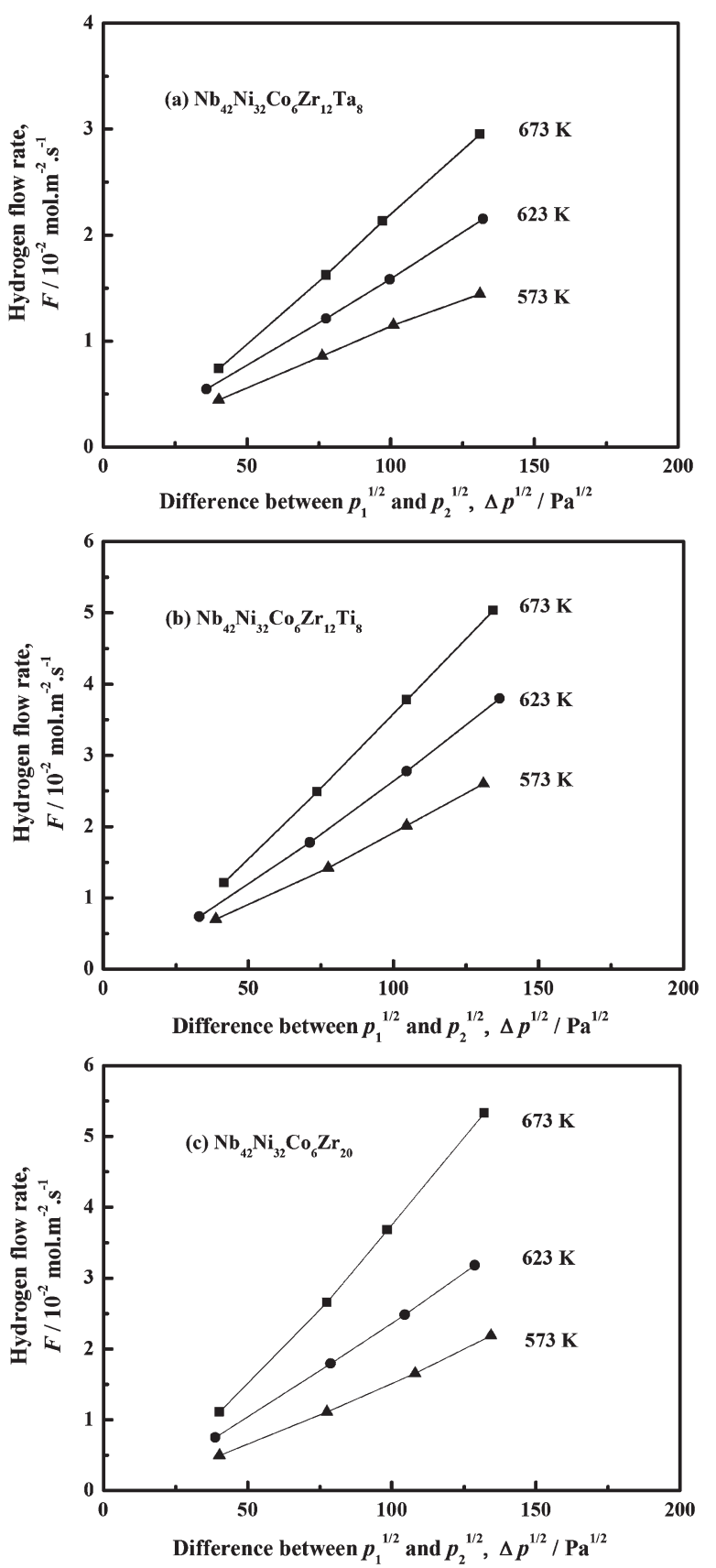

Fig. 3 Hydrogen flow rate $(F)$ vs. the pressure difference $(\Delta \sqrt{p})$ for $\mathrm{Nb}_{42} \mathrm{Ni}_{32} \mathrm{Co}_{6} \mathrm{Zr}_{12} \mathrm{M}_{8}(\mathrm{M}=\mathrm{Ta}, \mathrm{Ti}, \mathrm{Zr})$ alloys.

the $\mathrm{Nb}_{42} \mathrm{Ni}_{40} \mathrm{Co}_{18}$ base alloy $(913 \mathrm{~K})$. While $T_{\mathrm{x}}$ increased by replacing 8 at\% $\mathrm{Ni}$ with $\mathrm{Ta}(936 \mathrm{~K})$ or $\mathrm{Ti}(946 \mathrm{~K})$ of the $\mathrm{Nb}_{42} \mathrm{Ni}_{40} \mathrm{Co}_{6} \mathrm{Zr}_{12}$ alloy $(869 \mathrm{~K})$. These $T_{\mathrm{x}}$ values are much higher than other amorphous alloys except for a few ones (see Table 1 and Ref. 22). It indicates that the present Nbbased amorphous alloys possess good thermal stability as expected.

Figures 3(a)-(c) shows some representative hydrogen flow rate $(F)$ versus the pressure difference $\left(\Delta \sqrt{p},=p_{1}{ }^{1 / 2}-p_{2}{ }^{1 / 2}\right)$ relationship at different temperatures for the $\mathrm{Nb}_{42} \mathrm{Ni}_{32}-$ $\mathrm{Co}_{6} \mathrm{Zr}_{12} \mathrm{M}_{8}(\mathrm{M}=\mathrm{Ta}, \mathrm{Ti}, \mathrm{Zr})$ alloys, respectively. That of $\mathrm{Nb}_{42} \mathrm{Ni}_{40} \mathrm{Co}_{18-x} \mathrm{Zr}_{x}(x=0,4,12)$ alloys are not shown here. It is found that the hydrogen flow rate $(F)$ varied nearly linearly with the pressure difference $(\Delta \sqrt{p})$, this indicates that the diffusion of hydrogen atoms in the membrane is the

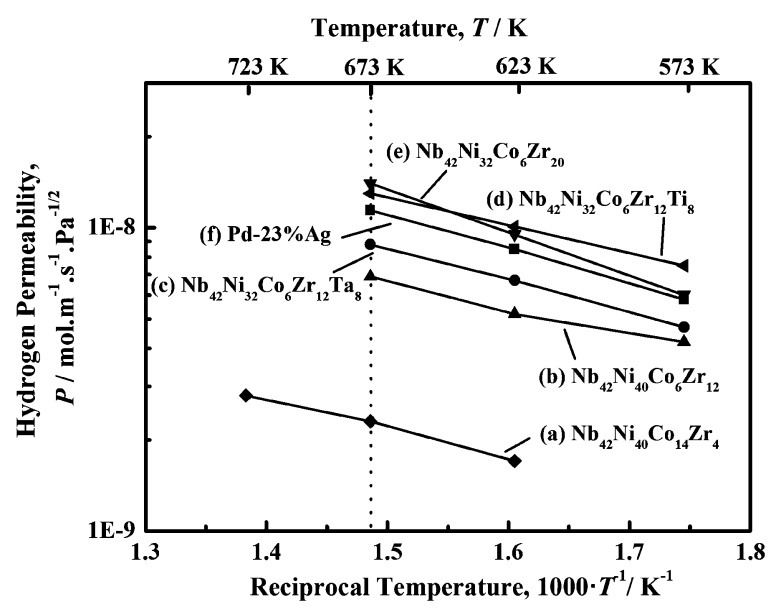

Fig. 4 Arrhenius plots of the $\mathrm{Nb}_{42} \mathrm{Ni}_{40} \mathrm{Co}_{18-x} \mathrm{Zr}_{x} \quad(x=4,12)$ and $\mathrm{Nb}_{42} \mathrm{Ni}_{32} \mathrm{Co}_{6} \mathrm{Zr}_{12} \mathrm{M}_{8}(\mathrm{M}=\mathrm{Ta}, \mathrm{Ti}, \mathrm{Zr})$ amorphous alloys as well as $\mathrm{Pd}-$ $23 \% \mathrm{Ag}$ alloy.

rate-limiting process for the alloys studied. ${ }^{11)}$ Hydrogen permeability of the $\mathrm{Nb}_{42} \mathrm{Ni}_{40} \mathrm{Co}_{18-x} \mathrm{Zr}_{x}(x=0,4,12)$ and $\mathrm{Nb}_{42} \mathrm{Ni}_{32} \mathrm{Co}_{6} \mathrm{Zr}_{12} \mathrm{M}_{8}(\mathrm{M}=\mathrm{Ta}, \mathrm{Ti}, \mathrm{Zr})$ alloys as well as $\mathrm{Pd}-$ $23 \% \mathrm{Ag}$ alloy at different temperatures are measured and listed in Table 2. For clarity, Arrhenius plots for $\mathrm{Nb}_{42}-$ $\mathrm{Ni}_{40} \mathrm{Co}_{18-x} \mathrm{Zr}_{x}(x=4,12)$ and $\mathrm{Nb}_{42} \mathrm{Ni}_{32} \mathrm{Co}_{6} \mathrm{Zr}_{12} \mathrm{M}_{8} \quad(\mathrm{M}=$ $\mathrm{Ta}, \mathrm{Ti}, \mathrm{Zr}$ ) alloys as well as $\mathrm{Pd}-23 \% \mathrm{Ag}$ standard sample are clearly demonstrated in Fig. 4 (a)-(f), the $\mathrm{Nb}_{42} \mathrm{Ni}_{40} \mathrm{Co}_{18}$ base alloy is not included as the data is too low. From Fig. 4 and Table 2 it is found that the hydrogen permeability of the $\mathrm{Nb}$-based alloys increased as the temperature increases. Permeability for the $\mathrm{Nb}_{42} \mathrm{Ni}_{40} \mathrm{Co}_{18}, \mathrm{Nb}_{42} \mathrm{Ni}_{40^{-}}$ $\mathrm{Co}_{14} \mathrm{Zr}_{4}, \quad \mathrm{Nb}_{42} \mathrm{Ni}_{40} \mathrm{Co}_{6} \mathrm{Zr}_{12}, \quad \mathrm{Nb}_{42} \mathrm{Ni}_{32} \mathrm{Co}_{6} \mathrm{Zr}_{12} \mathrm{Ta}_{8}, \quad \mathrm{Nb}_{42} \mathrm{Ni}_{32}$ $\mathrm{Co}_{6} \mathrm{Zr}_{12} \mathrm{Ti}_{8}$ and $\mathrm{Nb}_{42} \mathrm{Ni}_{32} \mathrm{Co}_{6} \mathrm{Zr}_{20}$ amorphous alloys and the $\mathrm{Pd}-23 \% \mathrm{Ag}$ alloy at $673 \mathrm{~K}$ are $0.03 \times 10^{-8}, 0.23 \times 10^{-8}$, $0.69 \times 10^{-8}, \quad 0.88 \times 10^{-8}, 1.30 \times 10^{-8}, 1.40 \times 10^{-8}$ and $1.14 \times 10^{-8} \mathrm{~mol} \cdot \mathrm{m}^{-1} \cdot \mathrm{s}^{-1} \cdot \mathrm{Pa}^{-1 / 2}$, respectively. The present permeability of $\mathrm{Pd}-23 \% \mathrm{Ag}$ alloy is a little bit lower than Hara's result. ${ }^{9)}$ This might be attributed to the different measurement equipment. It is worth to mention that hydrogen permeability of the $\mathrm{Nb}_{42} \mathrm{Ni}_{32} \mathrm{Co}_{6} \mathrm{Zr}_{12} \mathrm{Ti}_{8}$ and $\mathrm{Nb}_{42} \mathrm{Ni}_{32} \mathrm{Co}_{6} \mathrm{Zr}_{20}$ alloys is higher than the $\mathrm{Pd}-23 \% \mathrm{Ag}$ alloy in this study. It is also comparable with other amorphous alloys listed in Table 1.9-20)

According to Fick's first law and the Sievert's law, the hydrogen flow rate $F$ through the membrane can be described by the following equation; ${ }^{11,21)}$

$$
F=\frac{P \cdot\left(\sqrt{p_{1}}-\sqrt{p_{2}}\right)}{L}=\frac{D \cdot K \cdot\left(\sqrt{p_{1}}-\sqrt{p_{2}}\right)}{2 L},
$$

where $F$ represents the hydrogen flow rate $\left(\mathrm{mol} \cdot \mathrm{m}^{-2} \cdot \mathrm{s}^{-1}\right)$, $P$ is the hydrogen permeability $\left(\mathrm{mol} \cdot \mathrm{m}^{-1} \cdot \mathrm{s}^{-1} \cdot \mathrm{Pa}^{-1 / 2}\right), L$ is the thickness of the membrane $(\mathrm{m}), D$ is the diffusion coefficient $\left(\mathrm{m}^{2} \cdot \mathrm{s}^{-1}\right), K$ is the hydrogen absorption coefficient $\left(\mathrm{mol} \cdot \mathrm{m}^{-3} \cdot \mathrm{Pa}^{-1 / 2}\right)$, and $p_{1}, p_{2}$ are the hydrogen pressure of the upper and lower side $(\mathrm{Pa})$, respectively.

From the above equation, it is clear that the hydrogen permeation is controlled by both hydrogen absorption and hydrogen diffusion. From Fig. 4 and Table 2, it can be found that hydrogen permeability of the $\mathrm{Nb}_{42} \mathrm{Ni}_{40} \mathrm{Co}_{18}$ alloy is greatly enhanced by replacing $\mathrm{Co}$ and $\mathrm{Ni}$ with $\mathrm{Zr}$. Hydrogen 


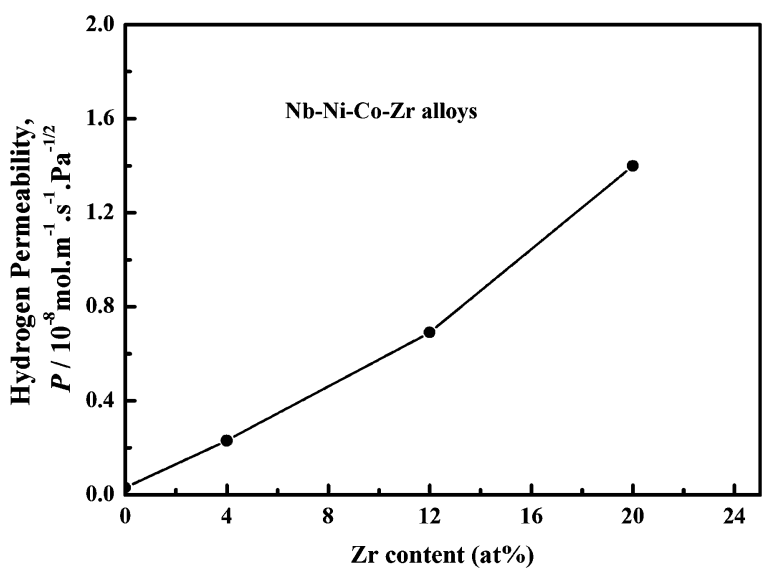

Fig. 5 Hydrogen permeability at $673 \mathrm{~K}$ vs. $\mathrm{Zr}$ content in the $\mathrm{Nb}-\mathrm{Ni}-\mathrm{Co}-\mathrm{Zr}$ quaternary alloy system.

permeability increased with higher $\mathrm{Zr}$ content on the overall. The correlation between the permeability and $\mathrm{Zr}$ content is more clearly demonstrated in Fig. 5. From Fig. 5, hydrogen permeability of the $\mathrm{Nb}-\mathrm{Ni}-\mathrm{Co}-\mathrm{Zr}$ alloy almost increases linearly with $\mathrm{Zr}$ content. Similar trend was also observed in $\mathrm{Ni}-\mathrm{Nb}-\mathrm{Zr}^{11,14)}$ system. As is reported by Aoki et al. ${ }^{24)}$ the hydrogen absorption in the $\mathrm{Ni}-\mathrm{Zr}$ system increased dramatically with $\mathrm{Zr}$ addition. Harris et al. ${ }^{25}$ ) also reported that hydrogen tends to stay between tetrahedral interstitial sites surrounded by $\mathrm{Zr}_{4}$ atoms rather than $\mathrm{Zr}_{3} \mathrm{Ni}_{1}$ or $\mathrm{Zr}_{2} \mathrm{Ni}_{2}$ sites. The increase of hydrogen permeability with $\mathrm{Zr}$ addition may also be attributed to an improved hydrogen absorption in the $\mathrm{Nb}-\mathrm{Ni}-\mathrm{Co}-\mathrm{Zr}$ system.

It is noticed from Fig. 4 and Table 2 that by substituting 8 at\% $\mathrm{Ni}$ with $\mathrm{Ta}$ or $\mathrm{Ti}$ in the $\mathrm{Nb}_{42} \mathrm{Ni}_{40} \mathrm{Co}_{6} \mathrm{Zr}_{12}$ alloy, the hydrogen permeability is also increased. The reason may lie in that Ta and Ti belong to the early transition metal (ETM), while Ni belongs to late transition metal (LTM). The ETMs commonly have higher affinity with hydrogen than the LTMs. ${ }^{21)}$ By addition of $\mathrm{Ta}$ or $\mathrm{Ti}$ and reduction of $\mathrm{Ni}$ content, hydrogen absorption property of the $\mathrm{Nb}_{42} \mathrm{Ni}_{40} \mathrm{Co}_{6} \mathrm{Zr}_{12}$ alloy is increased, resulting in the improvement of hydrogen permeability. This is in consistent with our previous result in $\mathrm{Ni}-\mathrm{X}-$ Zr alloys. ${ }^{15)}$

Moreover, from Fig. 1 it is clearly seen that the halo peak position is slightly shifted to lower angle with the increasing in $\mathrm{Zr}$ content in the quaternary $\mathrm{Nb}-\mathrm{Ni}-\mathrm{Co}-\mathrm{Zr}$ alloys. By replacing 8 at\% $\mathrm{Ni}$ with $\mathrm{Ti}$ or $\mathrm{Ta}$ in the $\mathrm{Nb}_{42} \mathrm{Ni}_{40} \mathrm{Co}_{6} \mathrm{Zr}_{12}$ alloy, the peak angle also become smaller. This peak shift is related with the increase in average distance between atoms according to Jiao's work. ${ }^{26)}$ From the geometric point of view, it is reasonable because the atomic radius of $\mathrm{Zr}$ $(0.160 \mathrm{~nm})$ is much larger than $\mathrm{Ni}(0.125 \mathrm{~nm})$ and $\mathrm{Co}$ $(0.125 \mathrm{~nm})$. The atomic radius of $\mathrm{Ti}(0.146 \mathrm{~nm})$ and $\mathrm{Ta}$ $(0.143 \mathrm{~nm})$ is also larger than $\mathrm{Ni}(0.125 \mathrm{~nm}) .{ }^{27)}$ The introduction of larger atoms ( $\mathrm{Ta}, \mathrm{Ti}$ and $\mathrm{Zr}$ ) leads to an increase in the average distance between atoms, the expansion of amorphous structure may be beneficial for hydrogen to pass through. In this way, the hydrogen permeation property is also enhanced.

As is demonstrated in Fig. 4 and Table 2, the $\mathrm{Nb}_{42} \mathrm{Ni}_{32}-$ $\mathrm{Co}_{6} \mathrm{Zr}_{20}$ alloy possess good hydrogen permeability compara-

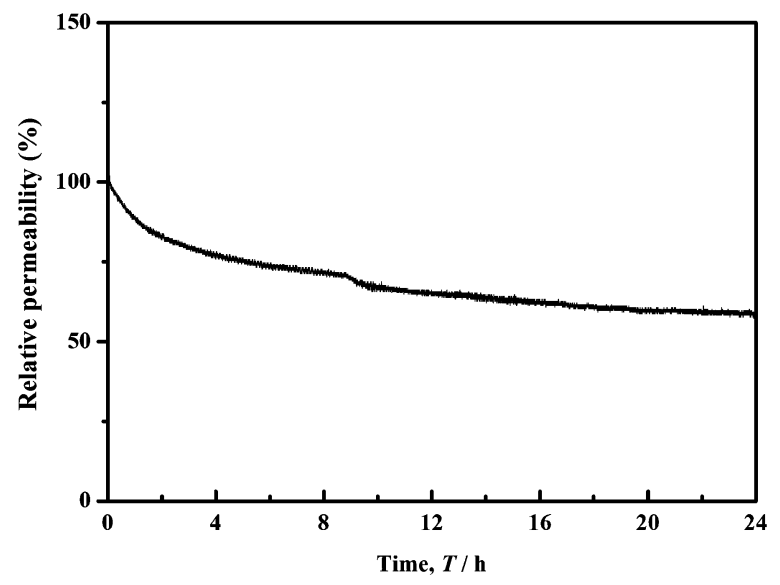

Fig. 6 Long term durability $(24 \mathrm{~h})$ test of the $\mathrm{Nb}_{42} \mathrm{Ni}_{32} \mathrm{Co}_{6} \mathrm{Zr}_{20}$ alloy for hydrogen permeation at $673 \mathrm{~K}$ under a constant pressure of $0.2 \mathrm{MPa}$.

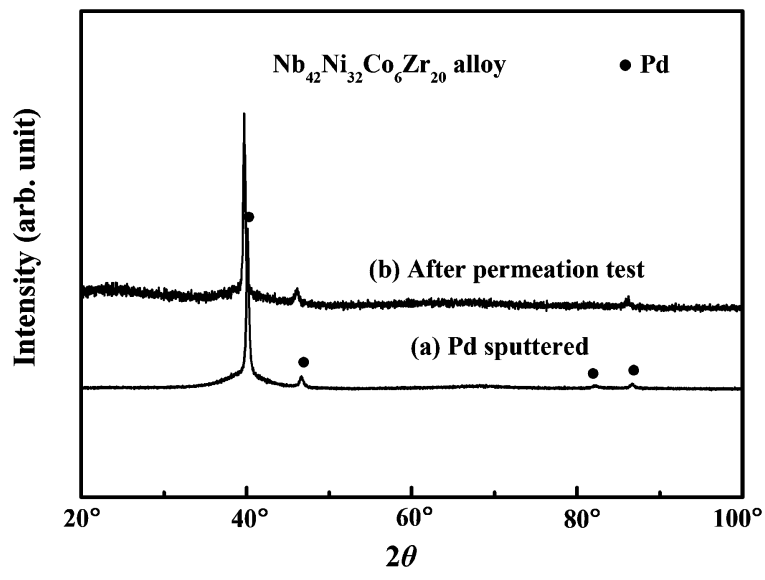

Fig. 7 XRD spectra of the $\mathrm{Nb}_{42} \mathrm{Ni}_{32} \mathrm{Co}_{6} \mathrm{Zr}_{20}$ alloy membrane (a) $\mathrm{Pd}$ sputtered and (b) after $24 \mathrm{~h}$ permeation test.

ble with that of $\mathrm{Pd}-23 \% \mathrm{Ag}$ alloy, also it is the highest among the Nb-based amorphous alloys studied (at $673 \mathrm{~K}$ ), so we further investigate its long term durability together with structural change before and after permeation test to see its practical performance.

Long term durability of the amorphous $\mathrm{Nb}_{42} \mathrm{Ni}_{32} \mathrm{Co}_{6} \mathrm{Zr}_{20}$ alloy membrane was performed by a $24 \mathrm{~h}$ permeation test at $673 \mathrm{~K}$ under a constant upper pressure of $0.2 \mathrm{MPa}$, the result is shown in Fig. 6. It can be seen that during the first few hours the permeability decreased slightly, and it remained nearly unchanged later on. The permeability after $24 \mathrm{~h}$ is $60 \%$ of the initial value. In contrast, both $\left(\mathrm{Ni}_{0.6} \mathrm{Nb}_{0.4}\right)_{55} \mathrm{Zr}_{40} \mathrm{Co}_{5}$ amorphous alloy ${ }^{16)}$ and the $\left(\mathrm{Ni}_{0.6} \mathrm{Nb}_{0.4}\right)_{70} \mathrm{Zr}_{30}$ amorphous alloy $^{20)}$ degrade rapidly over time. The present result indicates that the $\mathrm{Nb}_{42} \mathrm{Ni}_{32} \mathrm{Co}_{6} \mathrm{Zr}_{20}$ alloy membrane is very stable during the long term performance.

Figure 7 shows the XRD spectra of the $\mathrm{Nb}_{42} \mathrm{Ni}_{32} \mathrm{Co}_{6} \mathrm{Zr}_{20}$ alloy membrane (a) Pd sputtered and (b) after permeation test. There is no peak related to the crystallization of the membrane, which means that the membrane still possess its amorphous structure. Meanwhile, the peaks of Pd shifts to lower angle a little bit after the permeation test, this is caused by the hydrogen solution in $\mathrm{Pd}$, leading to a slightly expanded lattice. ${ }^{17)}$ 


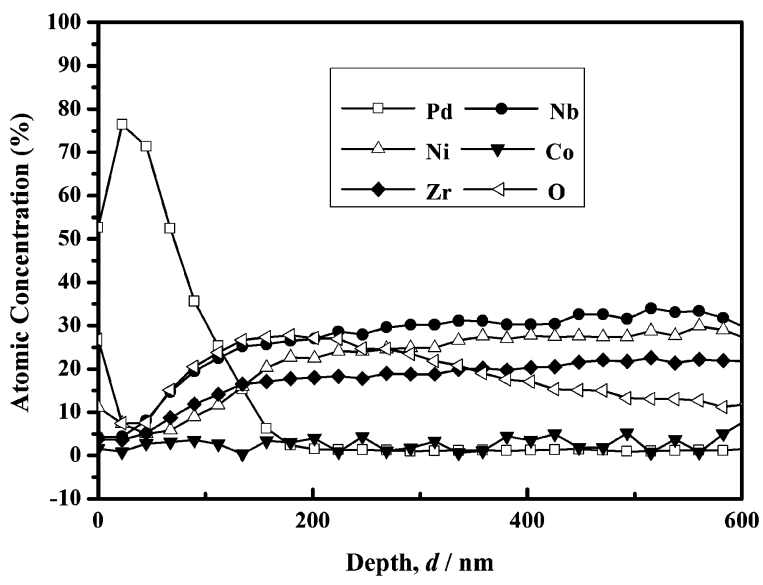

Fig. 8 AES depth profile of Pd-coated $\mathrm{Nb}_{42} \mathrm{Ni}_{32} \mathrm{Co}_{6} \mathrm{Zr}_{20}$ alloy membrane after $24 \mathrm{~h}$ permeation test.

Figure 8 shows the AES depth profile of the $\mathrm{Nb}_{42} \mathrm{Ni}_{32}$ $\mathrm{Co}_{6} \mathrm{Zr}_{20}$ alloy membrane after $24 \mathrm{~h}$ permeation test. From Fig. 8 we can see that the ratio of $\mathrm{Nb}, \mathrm{Ni}, \mathrm{Co}$ and $\mathrm{Zr}$ remain unchanged compared with the nominal composition, while the total amount decreased due to oxygen. This means that an oxidation layer formed after a $24 \mathrm{~h}$ long term permeation test, it will lead to a barrier for hydrogen to pass through. Meanwhile it is noticed that some $\mathrm{Pd}$ diffuse into the membrane, the depth is about $100 \mathrm{~nm}$. As a result, the catalytic property is damaged. Both oxidation and interdiffusion of $\mathrm{Pd}$ into the membrane are responsible for the property degradation after $24 \mathrm{~h}$ long term permeation test, as shown in Fig. 6.

\section{Conclusions}

In this work, $\mathrm{Nb}$-based $\mathrm{Nb}_{42} \mathrm{Ni}_{40} \mathrm{Co}_{18-x} \mathrm{Zr}_{x}(x=0,4,12)$ and $\mathrm{Nb}_{42} \mathrm{Ni}_{32} \mathrm{Co}_{6} \mathrm{Zr}_{12} \mathrm{M}_{8}(\mathrm{M}=\mathrm{Ta}, \mathrm{Ti}, \mathrm{Zr})$ amorphous alloy ribbons were successfully prepared by single roller meltspinning technique. They all exhibit high thermal stability with the crystallization temperature $\left(T_{\mathrm{x}}\right)$ exceeding $850 \mathrm{~K} . T_{\mathrm{x}}$ decreased while the hydrogen permeability increased with $\mathrm{Zr}$ addition in the $\mathrm{Nb}-\mathrm{Ni}-\mathrm{Co}-\mathrm{Zr}$ quaternary alloy system. Both $T_{\mathrm{x}}$ and the hydrogen permeability increased by substituting 8 at\% $\mathrm{Ni}$ with $\mathrm{Ta}$ or $\mathrm{Ti}$ in the $\mathrm{Nb}_{42} \mathrm{Ni}_{40} \mathrm{Co}_{6} \mathrm{Zr}_{12}$ alloy. Hydrogen permeability at $673 \mathrm{~K}$ for the $\mathrm{Nb}_{42} \mathrm{Ni}_{32} \mathrm{Co}_{6} \mathrm{Zr}_{12} \mathrm{Ti}_{8}$ and $\mathrm{Nb}_{42} \mathrm{Ni}_{32} \mathrm{Co}_{6} \mathrm{Zr}_{20}$ amorphous alloys are $1.30 \times 10^{-8}$ and $1.40 \times 10^{-8} \mathrm{~mol} \cdot \mathrm{m}^{-1} \cdot \mathrm{s}^{-1} \cdot \mathrm{Pa}^{-1 / 2}$, respectively, higher than that of the $\mathrm{Pd}-23 \% \mathrm{Ag}$ alloy $\left(1.14 \times 10^{-8}\right)$. In addition, permeability of the $\mathrm{Nb}_{42} \mathrm{Ni}_{32} \mathrm{Co}_{6} \mathrm{Zr}_{20}$ amorphous alloy decreased to $60 \%$ of the initial value while it still maintains amorphous structure after $24 \mathrm{~h}$ long term durability test. The degradation is attributed to oxidation and $\mathrm{Pd}$ interdiffussion. The present result indicates that the Nb-based amorphous alloys possess the potential of applying as a kind of hydrogen permeable membrane at high temperature.

\section{Acknowledgements}

This work was supported by the National Basic Research Program of China (Grant No. 2007CB613905), the National Natural Science Foundation of China (NSFC, Grant Nos. 50971073 and 51271095), and Ph.D. Programs Foundation of Ministry of Education of China (Grant No. 20120002110038).

\section{REFERENCES}

1) N. W. Ockwig and T. M. Nenoff: Chem. Rev. 107 (2007) 4078-4110.

2) S. Uemiya, N. Sato, H. Ando, Y. Kude, T. Matsuda and E. Kikuchi: J. Membr. Sci. 56 (1991) 303-313.

3) B. D. Morreale, M. V. Ciocco, B. H. Howard, R. P. Killmeyer, A. V. Cugini and R. M. Enick: J. Membr. Sci. 241 (2004) 219-224.

4) A. Inoue: Acta Mater. 48 (2000) 279-306.

5) J. Schroers and W. L. Johnson: Phys. Rev. Lett. 93 (2004) 255506.

6) K. F. Yao, F. Ruan, Y. Q. Yang and N. Chen: Appl. Phys. Lett. 88 (2006) 122106.

7) C. A. Schuh, T. C. Hufnagel and U. Ramamurty: Acta Mater. 55 (2007) 4067-4109.

8) S. N. Paglieri and J. D. Way: Sep. Purif. Rev. 31 (2002) 1-169.

9) S. Hara, K. Sakaki, N. Itoh, H. M. Kimura, K. Asami and A. Inoue: J. Membr. Sci. 164 (2000) 289-294.

10) S. Hara, N. Hatakeyama, N. Itoh, H. M. Kimura and A. Inoue: Desalination 144 (2002) 115-120.

11) S. Yamaura, Y. Shimpo, H. Okouchi, M. Nishida, O. Kajita, H. Kimura and A. Inoue: Mater. Trans. 44 (2003) 1885-1890.

12) S. Yamaura, Y. Shimpo, H. Okouchi, M. Nishida, O. Kajita and A. Inoue: Mater. Trans. 45 (2004) 330-333.

13) Y. Shimpo, S. Yamaura, H. Okouchi, M. Nishida, O. Kajita, H. Kimura and A. Inoue: J. Alloy. Compd. 372 (2004) 197-200.

14) S. Yamaura, M. Sakurai, M. Hasegawa, K. Wakoh, Y. Shimpo, M. Nishida, H. M. Kimura, E. Matsubara and A. Inoue: Acta Mater. 53 (2005) 3703-3711.

15) S. Yamaura, S. Nakata, H. Kimura, Y. Shimpo, M. Nishida and A. Inoue: Mater. Trans. 46 (2005) 1768-1770.

16) Y. Shimpo, S. Yamaura, M. Nishida, H. Kimura and A. Inoue: J. Membr. Sci. 286 (2006) 170-173.

17) D. Y. Lee and E. Fleury: Met. Mater. Int. 14 (2008) 545-548.

18) J. B. Qiang, W. Zhang, S. Yamaura and A. Inoue: Mater. Trans. 50 (2009) 1236-1239.

19) S. Yamaura and A. Inoue: J. Membr. Sci. 349 (2010) 138-144.

20) S. N. Paglieri, N. K. Pal, M. D. Dolan, S. M. Kim, W. M. Chien, J. Lamb, D. Chandra, K. M. Hubbard and D. P. Moore: J. Membr. Sci. 378 (2011) 42-50.

21) J. W. Phair and R. Donelson: Ind. Eng. Chem. Res. 45 (2006) 56575674.

22) M. D. Dolan, N. C. Dave, A. Y. Ilyushechkin, L. D. Morpeth and K. G. McLennan: J. Membr. Sci. 285 (2006) 30-55.

23) D. Meng, J. Yi, D. Q. Zhao, D. W. Ding, H. Y. Bai, M. X. Pan and W. H. Wang: J. Non-Cryst. Solids 357 (2011) 1787-1790.

24) K. Aoki, M. Kamachi and T. Masumoto: J. Non-Cryst. Solids 61-62 (1984) 679-684.

25) J. H. Harris, W. A. Curtin and M. A. Tenhover: Phys. Rev. B 36 (1987) 5784-5797.

26) W. Jiao, D. Q. Zhao, D. W. Ding, H. Bai and W. H. Wang: J. NonCryst. Solids 358 (2012) 711-714.

27) O. N. Senkov and D. B. Miracle: Mater. Res. Bull. 36 (2001) 21832198. 